\title{
CHARACTERIZATION OF FLOTATION TAILINGS FROM SAMARCO AND OTHER VARIETIES OF SAND FOR USE IN SAND MOLDING IN THE FOUNDRY INDUSTRY
}

Ricardo Augusto Martins Figueiredo Sávio José de Oliveira ' Guilherme Francisco de Sales Silva ' Cláudio Batista Vieira ${ }^{2}$ Maria Aparecida Pinto ${ }^{2}$ Leandro Moreira Carneiro ' Varadarajan Seshadri ${ }^{3}$ Denilson Rodrigues de Araújo ${ }^{4}$ Gil Ribeiro Vilela Neto ${ }^{4}$

\begin{abstract}
Foundry sand used for molding should have specific properties so that molds with adequate strength, porosity, etc to produce defect free castings. Thus, characterization of two types of flotation tailings from the mineral processing of itabirites and three types of base sand for molding have been carried out. The resulting properties have been compared to evaluate the suitability of use of typical flotation tailing for the molding process. The main properties determined are the grain shape and structure, chemical composition, grain size distribution, fineness modulus, fines content, moisture content and loss on ignition. Furthermore other properties of these sands prepared with binders have been compared like compactability, permeability and green compressive strength for green sand. For cold set and sodium silicate/ $\mathrm{CO}_{2}$ processes properties like tensile strength and bending strength have been evaluated. The results show that the flotation tailing SA2 presented a good potential of use in the foundry.
\end{abstract}

Keywords: Flotation tailing; Sand molding; Foundry industry; Sustainability.

\section{CARACTERIZAÇÃO DE REJEITOS DE FLOTAÇÃO DA SAMARCO E OUTRAS VARIEDADES DE AREIA PARA USO EM MOLDAGEM NA FUNDIÇÃO}

\section{Resumo}

As areias de fundição usadas para moldagem devem apresentar propriedades específicas, como adequada resistência, porosidade, etc, para produzir peças livres de defeitos. Assim, foram caracterizados dois tipos de rejeitos de flotação do beneficiamento do itabirito e três tipos de areia-base para moldagem. Os resultados foram comparados para avaliar adequação do uso do rejeito de flotação no processo de moldagem. As principais propriedades determinadas foram: forma e estrutura dos grãos, composição química, distribuição granulométrica, módulo de finura, quantidade de finos, umidade e perda por calcinação. Ademais, outras propriedades dessas areias misturadas com aglomerantes foram comparadas, como compactabilidade, permeabilidade e resistência à compressão a verde para areia verde. Para os processos de areia com resina e silicato de sódio/ $\mathrm{CO}_{2}$ foram avaliadas as resistência à tração e à flexão. Os resultados mostraram que o rejeito de flotação SA2 apresentou bom potencial para uso na fundição.

Palavras-chave: Rejeito de flotação; Areia de moldagem; Fundição; Sustentabilidade.

'Rede Temática em Engenharia de Materiais, Universidade Federal de Ouro Preto - UFOP, Ouro Preto, MG, Brasil. E-mail: rickugol@yahoo.com.br ${ }^{2}$ Departamento de Engenharia Metalúrgica e de Materiais, Universidade Federal de Ouro Preto - UFOP, Ouro Preto, MG, Brasil.

${ }^{3}$ Departamento de Engenharia Metalúrgica e de Materiais, Universidade Federal de Minas Gerais - UFMG, Belo Horizonte, MG, Brasil.

${ }^{4}$ Samarco, Belo Horizonte, MG, Brasil.

2176-1523 (C) 2019 Associação Brasileira de Metalurgia, Materiais e Mineração. Published by ABM. This is an open access paper, published under the Creative Commons CC BY-NC-ND license (Attribution-NonCommercial-NoDerivs) - https://creativecommons.org/licenses/ by-nc-nd/4.0/. 


\section{INTRODUCTION}

Itabirite is a type of metamorphic rock, characterized by alternate layers of silica and iron oxide [I]. The main itabiritic ore processing plants in Brazil operate through reverse cationic flotation to produce hematitic concentrate as main product and a sandy material as flotation tailing, which are normally stored in the tailings dams. The alternatives for utilization of these flotation tailings from the itabirite processing can be considered as a strategy for waste utilization and to minimize harmful effects in respect of environmental aspects, besides contributing to reducing the amount of tailings stored in the dams, apart from economic advantages of waste utilization [2]. There are many other existing reuse practices, for theses materials such as the manufacture of ceramics, use in pavements, and other applications [2-4]. In this work, use of these tailings as base sand for mold making in the foundry industry is investigated.

\section{I.I Molding Sand}

The molding sand is basically composed of the base sand and some binder material like bentonite. Various varieties of sand have been used as mold materials in the foundry industry. Silica sand is the most commonly used mold material because of its abundance, low cost and high quality obtained for mold making [5].

In order to ascertain that sand is suitable for molding in the foundry industry, it is essential that sand characterization tests are carrried out in a systematic manner. The main properties of sand that are important for its use in the molding process are: adequate permeability for gas flow, narrow range of granulometric distribution, high degree of refractoriness, proper grain shape, high erosion resistance and good mechanical strength [6,7].

There are few contributions related to this study in the literature. The objective of the present work is to carry out analytical and technological characterization of silica sands originating from itabirite mineral processing and different other sources in order to evaluate the possibility of the use of these varieties in commercial sand molding processes in the foundries.in Brazil.

\section{METHODOLOGY}

\section{I Materials}

The sand samples characterized in this work are the following: Two sand samples from flotation tailings from Samarco, namely SAI and SA2, two sand samples from an operating foundry company, namely $\mathrm{NI}$ (virgin sand) and $\mathrm{PI}$ (cold set used sand with phenolic-urethane resin) and a standard reference sand sample (ST). The results of the ST sand characterization tests were taken as reference standard for comparison of results obtained for SAI, SA2, NI and PI.

\subsection{Analytical Characterization}

The methodology adopted for analytical characterization with the respective Committee of Studies on Raw Materials (CEMP) [8] standard and the equipment used for the tests are presented in the flow sheet in Figure I.

\subsection{Technological Characterization}

The methodology adopted for technological characterization in laboratory scale with the binder content, the respective CEMP [8] standard and the equipment used is presented in the flow sheet in Figure 2.

In the cold set process, with phenolic-urethane resin, the tensile and bending strengths were carried out at the time intervals of $0 \mathrm{~h}, 1 \mathrm{~h}, 2 \mathrm{~h}, 4 \mathrm{~h}, 6 \mathrm{~h}, 8 \mathrm{~h}, 12 \mathrm{~h}$ and $24 \mathrm{~h}$ to evaluate the behavior of the mixture as a function of time. For the sodium silicate/ $\mathrm{CO}_{2}$ process the gassing time of this process was calculated in order to obtain the best performance in the tests [9].

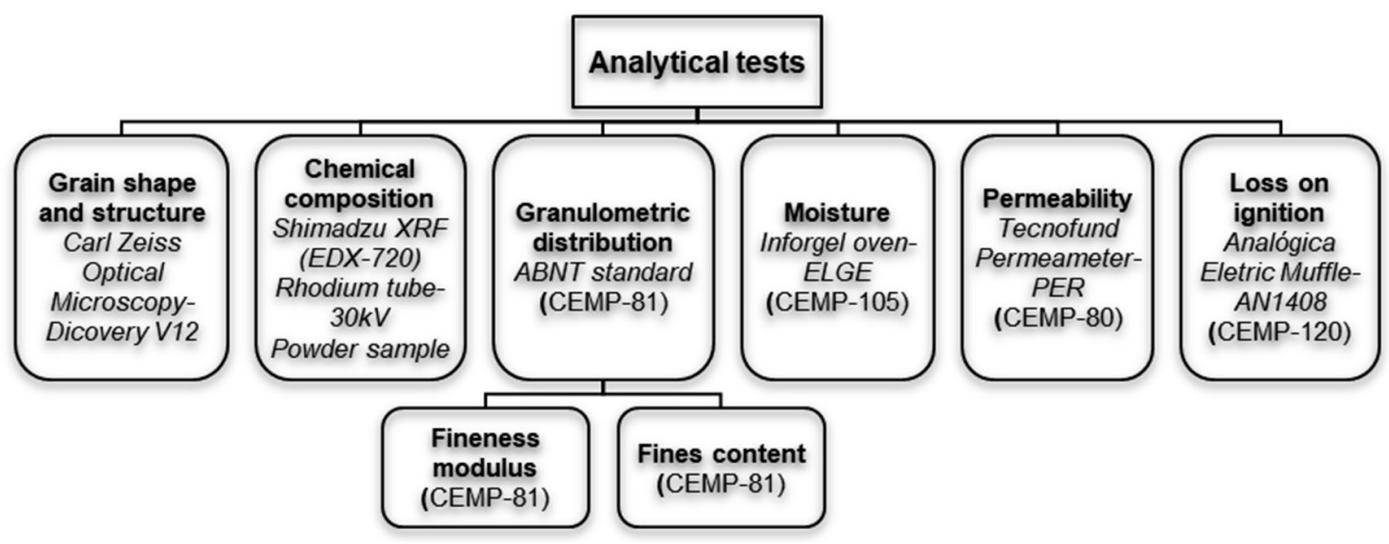

Figure I. Flow sheet summarizing the analytical characterization methodology. 


\section{RESULTS AND DISCUSSION}

The results of the analytical and technological characterization of the sand samples are given below.

\section{I Analytical Characterization}

Analysis of grain shape and structure are presented in Figure 3 and Table I.

The SAI and SA2 sands present angular and fractured grains. The ST, NI and PI sands present compact and subangular grains. According to Peixoto [10], the subangular grains are most suitable for making sand molds. A remaining resin layer from prior uses is observed on the surface of the $\mathrm{PI}$ sand. The angularity and the fractures present in the sand grains $S A I$ and SA2 are due to the iron ore grinding procedures. Sand with such characteristics may result in weak molds and generate large amount of fines during molding.

The results of the $\mathrm{X}$-ray fluorescence spectroscopy analysis is given in Table 2 .

The sands $\mathrm{SAI}$ and $\mathrm{SA} 2$ have $\mathrm{SiO}_{2}$ contents $85.82 \%$ and $93.35 \%$, respectively. The second frequently occurring compound in SAI and SA2 sands is iron oxide, around $13.83 \%$ and $6.20 \%$, respectively. The ST, NI and PI sands are composed of $98.81 \%, 98.29 \%$ and $82.48 \%$ of $\mathrm{SiO}_{2}$, respectively. The $\mathrm{PI}$ sand presents a considerable amount of $\mathrm{Cr}_{2} \mathrm{O}_{3},(10.22 \%)$.

The minimum silica content in sands varies according to the metal to be cast, and may be as low as $80 \%$ for lower melting alloys and above $90 \%$ for alloys of cast iron and steel [I I]. The ST and NI sands are the ones with the highest purity among the analyzed samples. PI sand has a large amount of chromium oxide due to the chromite sand used in the facing of the castings.

Figure 4 shows the result of the granulometric distribution of the sands.

SAI sand has a wide range of granulometric distribution, with material concentrations in several sieves. The SA2, $\mathrm{ST}, \mathrm{NI}$ and $\mathrm{PI}$ sands present sand concentrations in few sieves. A wide particle size distribution, as in sand SAI, can cause problems of permeability and defects in the parts [7]. The other sands present a concentration of their grains above $70 \%$ in three consecutive sieves, as recommended by some authors $[5,7,12]$.

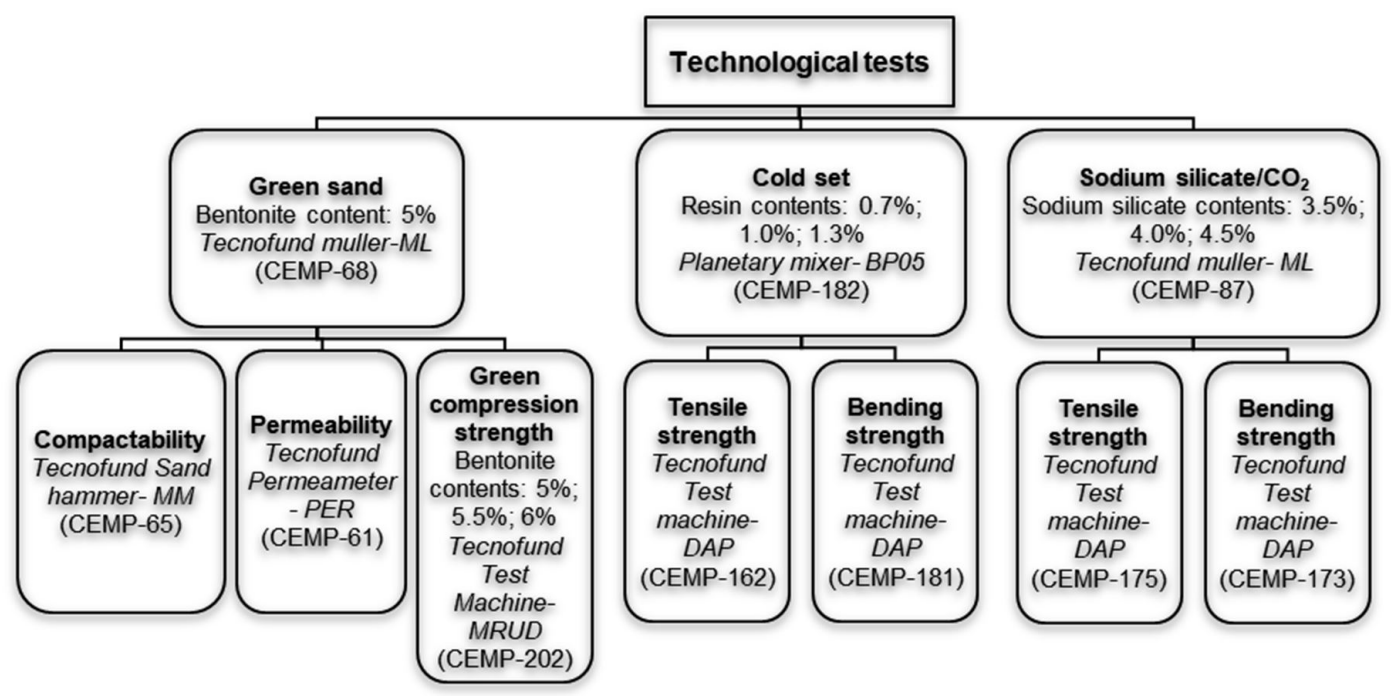

Figure 2. Flow sheet summarizing the technological characterization methodology.

Table I. Grain shape and structure

\begin{tabular}{lccccc}
\hline \multicolumn{1}{c}{ Samples } & SAI & SA2 & NI & PI & ST \\
\hline For Grain shape & Angular & Angular & Subangular & Subangular & Subangular \\
Structure of grains & Fratured & Fratured & Compact & Compact & Compact \\
\hline
\end{tabular}

Table 2. X-ray fluorescence spectroscopy analysis of different samples

\begin{tabular}{lcccrc}
\hline \multicolumn{1}{c}{ Chemical species } & SAI & SA2 & NI & PI & ST \\
\hline $\mathrm{SiO}_{2}$ & $85.82 \%$ & $93.35 \%$ & $98.29 \%$ & $82.48 \%$ & $98.81 \%$ \\
$\mathrm{Fe}_{2} \mathbf{O}_{3}$ & $13.83 \%$ & $6.20 \%$ & $0.19 \%$ & $6.35 \%$ & $0.65 \%$ \\
$\mathbf{W O}_{3}$ & $0.12 \%$ & $0.31 \%$ & $0.35 \%$ & $0.31 \%$ & $0.37 \%$ \\
$\mathrm{Cr}_{2} \mathbf{O}_{3}$ & - & - & - & $10.22 \%$ & - \\
Others & $0.23 \%$ & $0.14 \%$ & $1.17 \%$ & $0.64 \%$ & $0.17 \%$ \\
\hline
\end{tabular}




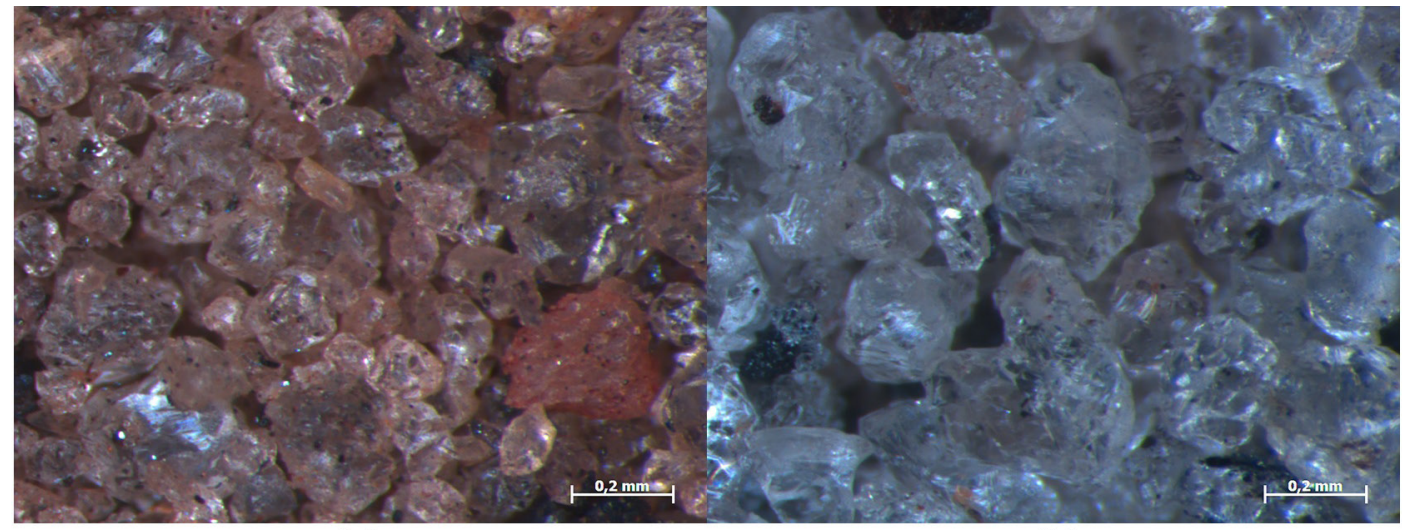

(a)

(b)

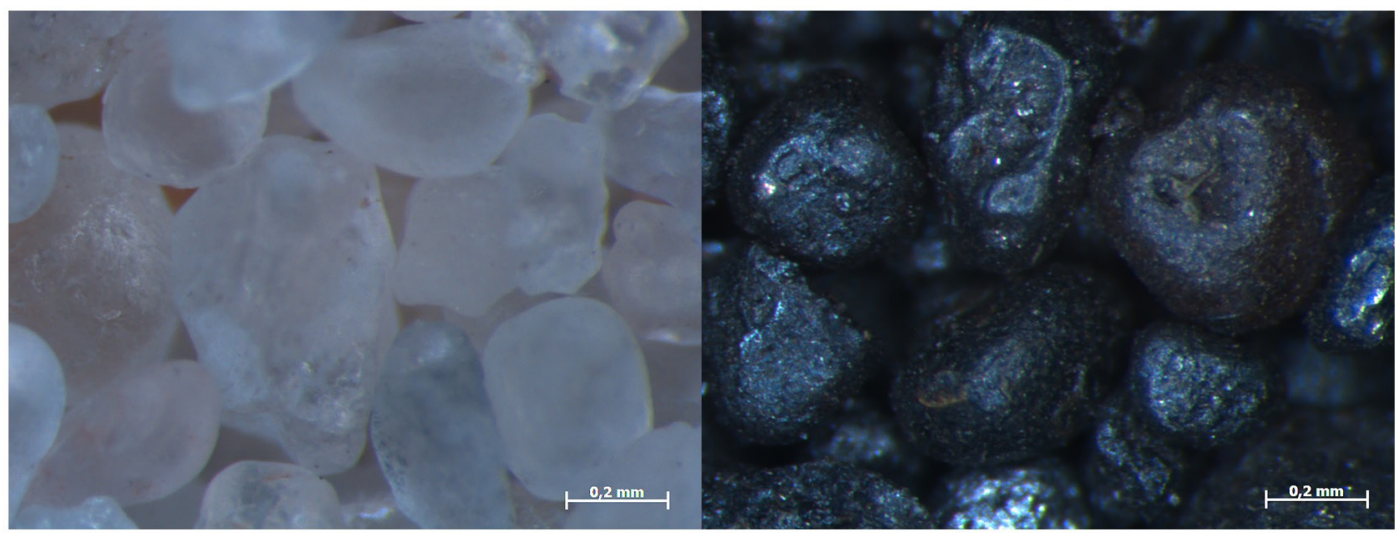

(c)

(d)

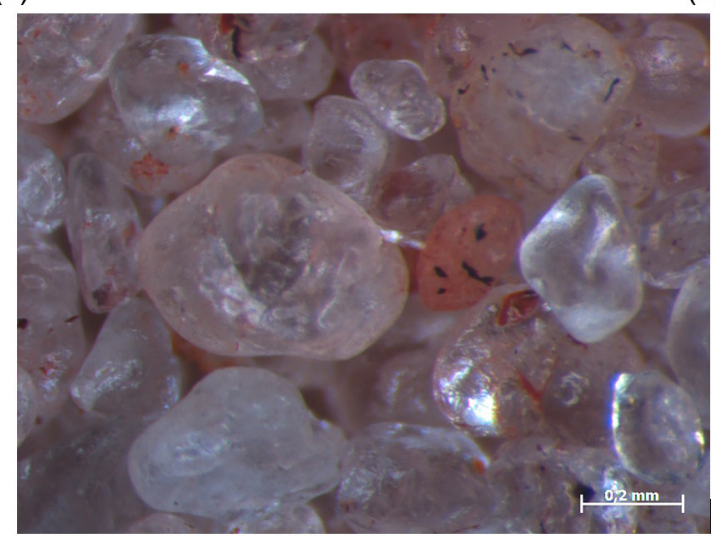

(e)

Figure 3. Optical microscopy images with 100x magnification of the SAI (a), SA2 (b), NI (c), PI (d) and ST (e).

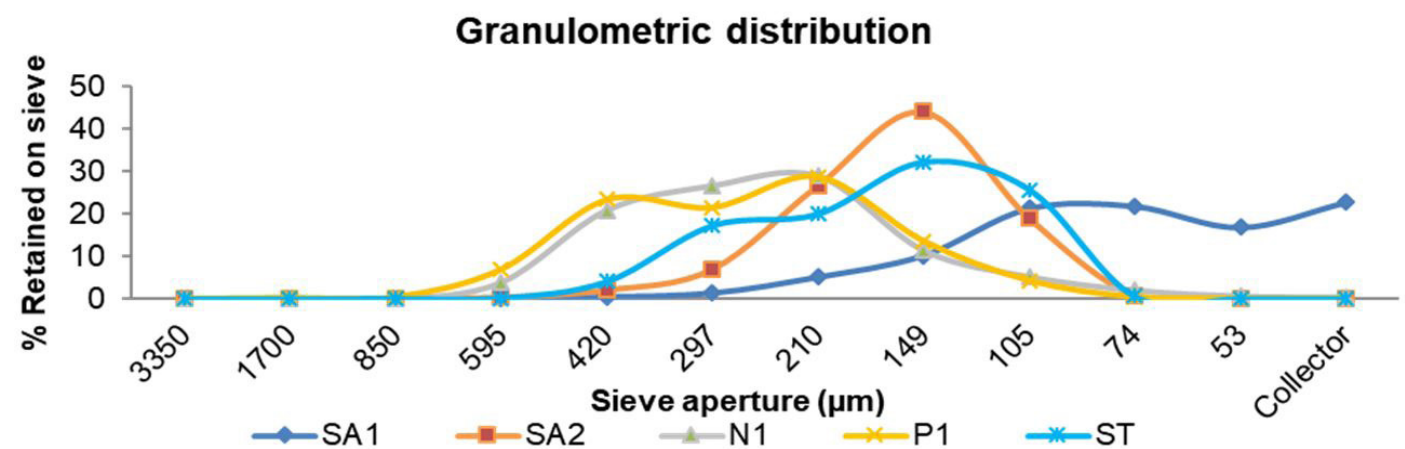

Figure 4. Granulometric distribution of the sands. 
Table 3 shows the values of fineness modulus, fines content, moisture, permeability and loss on ignition of the samples.

The NI and PI sands have smaller fineness modules than the others, being classified as medium sand (50.47 AFS) and coarse sand (46.34 AFS), respectively. The SA2 and ST sands are classified as medium sands and have fineness modules of 68. I 7 AFS and 67.27 AFS, respectively. The SAI sand features the finest fineness modulus, 165.45 AFS, being a very fine sand. The SAI, SA2, NI, PI and ST sands have permeability of $8 \mathrm{~cm}^{4} \mathrm{~g}^{-1} \mathrm{~min}^{-1}, 122 \mathrm{~cm}^{4} \mathrm{~g}^{-1} \mathrm{~min}^{-1}, 161 \mathrm{~cm}^{4} \mathrm{~g}^{-1} \mathrm{~min}^{-1}$, $190 \mathrm{~cm}^{4} \mathrm{~g}^{-1} \mathrm{~min}^{-1}$ and $103 \mathrm{~cm}^{4} \mathrm{~g}^{-1} \mathrm{~min}^{-1}$, respectively. The fine content of the sands SAI, SA2, NI, PI and ST are, respectively, $61.52 \%, 0.95 \%, 2.97 \%, 0.59 \%$ and $0.64 \%$.

Larger is the modulus of fineness of a sand, smaller is the average size of its grains, therefore the SAI sand is the finest. The SA2 and ST sands present a similar average size of their grains, which also is the case with $\mathrm{NI}$ and $\mathrm{PI}$ sands. The permeability values are directly related to the average grain size and the fines content of the material. The SAI sand has a low permeability value, (8 AFS), mainly due to its high content of fines. On the other hand, the NI and $\mathrm{PI}$ sands present higher permeabilities, as they have coarser grains and low content of fines. Permeability of the sand should be sufficient for flow of gases out of the mold and their minimum values vary according to the alloy to be cast [13]. This aspect is vital to produce defect free castings.

The moisture content of the sands SA I, SA2, NI, PI and ST was, respectively, 0.05\%, 0.04\%, 0.03\%, 0.20\% and $0.02 \%$. It is recommended that the humidity does not exceed values above $0.1 \%$ [14] in order to avoid defects in parts. The $\mathrm{PI}$ sand $(0.2 \%)$ was the only one that exceeded the stipulated value.

The loss on ignition (LOI) of sands SAI, SA2, NI, $\mathrm{PI}$ and ST was $0.52 \%, 0.35 \%, 0.01 \%, 2.23 \%$ and $0.07 \%$, respectively. The LOI should have the lowest possible value, but values of up to $2 \%$ are acceptable [15]. Almost all the sands had values of LOI below $1 \%$ with exception of PI sand that presented $2.23 \%$.

\subsection{Technological Characterization}

The results of the sands studied for green sand, cold set with phenolic-urethane resin and sand with sodium silicate $/ \mathrm{CO}_{2}$ processes are given below.

\subsection{Green sand}

The results of tests of green sand process samples are shown in Table 4.

The compactability of SAI, NI and ST sands was $47 \%$ while SA2 was $48 \%$. The value of the compactability of green sand is a measure that evaluates the conditions of its workability and its ideal value is $47 \% \pm 1 \%$, according to CEMP-68. All the sand samples were within the stipulated standards.

The SAI, SA2, NI and ST sands have the following permeability values, namely $18 \mathrm{~cm}^{4} \mathrm{~g}^{-1} \mathrm{~min}^{-1}, 147 \mathrm{~cm}^{4} \mathrm{~g}^{-1} \mathrm{~min}^{-1}$, $268 \mathrm{~cm}^{4} \mathrm{~g}^{-1} \mathrm{~min}^{-1}$ and $144 \mathrm{~cm}^{4} \mathrm{~g}^{-1} \mathrm{~min}^{-1}$, respectively. These results were consistent with the permeability results of their respective base sands. SA2 and ST sands also have near permeabilities, $147 \mathrm{~cm}^{4} \mathrm{~g}^{-1} \mathrm{~min}^{-1}$ and $144 \mathrm{~cm}^{4} \mathrm{~g}^{-1} \mathrm{~min}^{-1}$, respectively.

The green compressive strength of the SAI, SA2, $\mathrm{NI}$ and ST sands amount to $10.75 \mathrm{~N} \mathrm{~cm}^{-2}, 7.32 \mathrm{~N} \mathrm{~cm}^{-2}$, $12.13 \mathrm{~N} \mathrm{~cm}^{-2}$ and $13.03 \mathrm{~N} \mathrm{~cm}^{-2}$, respectively. The sand SAI has a value higher than SA2 $\left(10.75 \mathrm{~N} \mathrm{~cm}^{-2}\right.$ and $7.32 \mathrm{~N} \mathrm{~cm}^{-2}$, respectively), which may be due to the presence of some clay which could also act as a binder.

Table 5 presents the resistance values of sand SA2 for variations of bentonite contents.

Table 3. Physical parameters of samples tested

\begin{tabular}{|c|c|c|c|c|c|}
\hline Sample & SAI & SA2 & NI & $\mathbf{P I}$ & ST \\
\hline Fineness modulus/ AFS & 164.45 & 68.17 & 50.47 & 46.34 & 67.27 \\
\hline Sand classification & Very fine & Medium & Medium & Coarse & Medium \\
\hline Fines content/ \% & 61.52 & 0.95 & 2.97 & 0.59 & 0.64 \\
\hline Moisture/ \% & 0.05 & 0.04 & 0.03 & 0.20 & 0.02 \\
\hline Permeability $/ \mathrm{cm}^{4} \mathrm{~g}^{-1} \mathrm{~min}^{-1}$ & 8 & 122 & 161 & 190 & 103 \\
\hline Loss on ignition/ \% & 0.52 & 0.35 & 0.01 & 2.23 & 0.07 \\
\hline
\end{tabular}

Table 4. Results of green sand sample tests

\begin{tabular}{lcccc}
\hline \multicolumn{1}{c}{ Sample } & SAI & SA2 & NI & ST \\
\hline Compactability/ \% & 47 & 48 & 47 & 47 \\
Permeability/ AFS & 18 & 147 & 268 & 144 \\
Green compressive strength/ $\mathbf{~}$ cm $^{-2}$ & 10.75 & 7.32 & 12.13 & 13.03 \\
\hline
\end{tabular}

Table 5. Results of tests with different bentonite contents

\begin{tabular}{cccc}
\hline Sample & SA2-5.0\% & SA2-5.5\% & SA2-6.0\% \\
\hline Green compressive strength $/ \mathbf{N ~ c m}^{-2}$ & 7.32 & 7.91 & 8.74 \\
\hline
\end{tabular}


The value of the green compressive strength with $5.0 \%$, $5.5 \%$ and $6.0 \%$ of bentonite was $7.32 \mathrm{~N} \mathrm{~cm}^{-2}, 7.91 \mathrm{~N} \mathrm{~cm}^{-2}$ and $8.74 \mathrm{~N} \mathrm{~cm}^{-2}$. The increase from $5.0 \%$ to $5.5 \%$ in the bentonite content represented an increase of $8.06 \%$ of resistance $\left(7.32 \mathrm{~N} \mathrm{~cm}^{-2}\right.$ to $\left.7.91 \mathrm{~N} \mathrm{~cm}^{-2}\right)$. When increased from $5.0 \%$ to $6.0 \%$, the increase in resistance was $19.40 \%$ $\left(7.32 \mathrm{~N} \mathrm{~cm}^{-2}\right.$ to $\left.8.74 \mathrm{~N} \mathrm{~cm}^{-2}\right)$. This result implies that the $1 \%$ increase in the amount of binder results in approximately $1 \%$ in the increase of resistance of sand SA2.

\subsubsection{Cold set with phenolic-urethane resin}

The result of tensile strength tests is represented in Figure 5.

The ST sand has the highest values in all intervals. On the other hand, sand SAI has the lowest values of tensile strength. The SA2, NI and PI sands reached intermediate values. The $\mathrm{NI}$ sand reached significant values in the first two hours and then their values were close to the PI and SA2 sands. SA2 sand presented lower values when compared to ST.

The results for different resin additions to the SA2 sand, and the resulting tensile strength values in comparison to ST sand, are shown in Figure 6.

As the amount of binder in the SA2 sand $(0.7 \%, 1.0 \%$ and $1.3 \%$ ) is increased, the tensile strength of the blend also increases. It is observed that in most of the intervals the values of tensile strength of the sand SA2 with I.3\% of binder is near or some superior to that of sand ST. The increase in binder content from $0.7 \%$ to $1.0 \%$ represents an average increase in tensile strength values by $58 \%$ and increase of the same from $0.7 \%$ to $1.3 \%$ resulted in an average increase of $143 \%$ in tensile strength in the case of SA2.

Figure 7 shows the result of the bending strength of the sands.

The ST sand obtained the highest values of bending strength, while the SAI sand has the lowest values. The NI and SA2 sands presented very close values in the first 2 hours of the test, and, from this interval, the values of resistance of the former are higher than those of the latter. To evaluate the behavior of sands with organic binders, bending strength tests are the most widely applied for the quality control of casting sand [6]. When compared to PI sand, SA2 sand presented higher values at most intervals.

The values of bending strength with increasing resin content in sand SA2 are shown in the Figure 8.

The increase of the resin content in the SA2 sand resulted in an increase of bending strength of the same. The result is satisfactory, when compared with the values obtained for ST sand. In most of the time intervals the sand with I. $3 \%$ of binder presents resistance values superior to ST sand. The sand with I.0\% binder shows values close to the ST sand in the first two intervals. The variation from

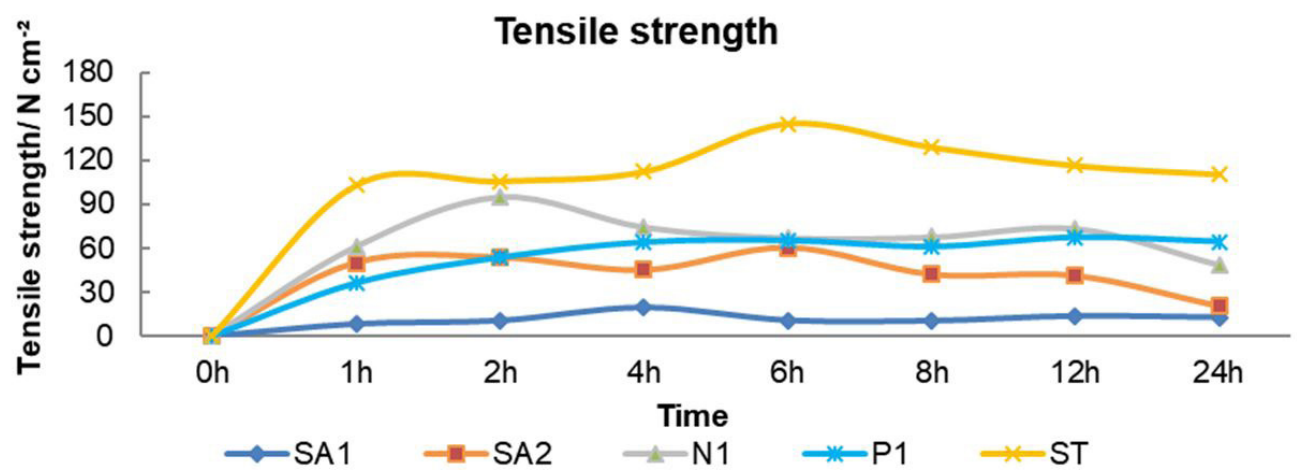

Figure 5. Tensile strength as a function of the time of cold set tests.

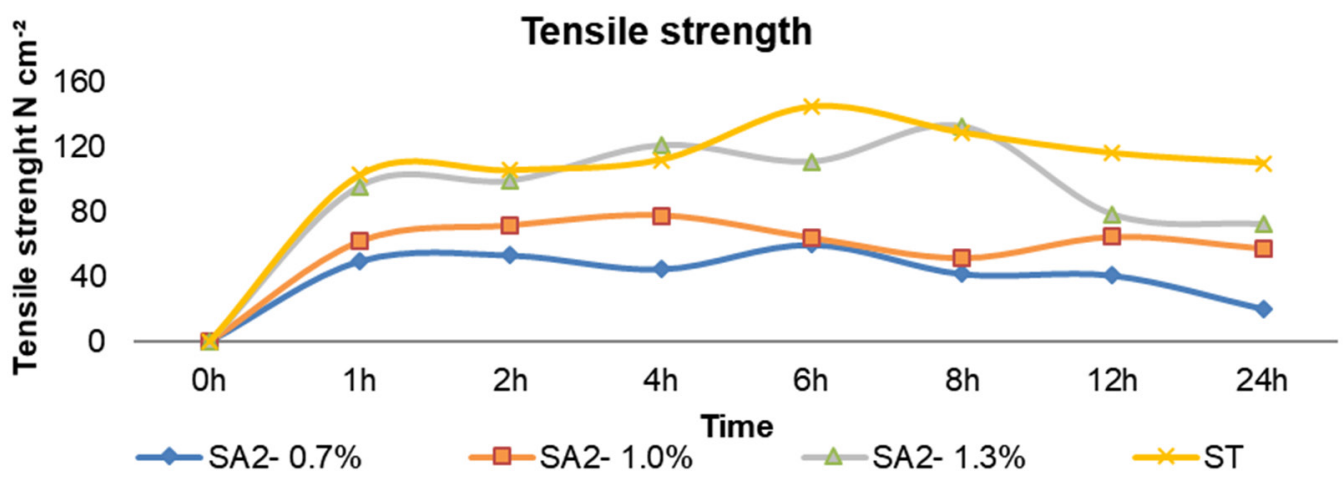

Figure 6. Tensile strength as a function of time: variation of the resin content of sand SA2. 
$0.7 \%$ to $1.0 \%$ of binder increased the resistance value by $6 \%$ while the variation from $0.7 \%$ to $1.3 \%$ increased on average by $77 \%$ of the average value of bending strength.

\subsubsection{Sand with sodium silicate $/ \mathrm{CO}_{2}$}

The results of tensile strength and bending strength tests with standard sodium silicate content $(3.5 \%)$ are shown in Table 6.

In Table 7, the results of the variations of the sodium silicate content for strength and bending strength tests with the $\mathrm{SA} 2$ sand are given.

For the tensile strength test, with the binder standard content (3.5\%), the highest value was obtained for ST sand $\left(33.57 \mathrm{~N} \mathrm{~cm}^{-2}\right)$ and the lowest for sand SAI $\left(19.4 \mathrm{~N} \mathrm{~cm}^{-2}\right)$.
The SA2 and NI sands reached close values, $25.97 \mathrm{~N} \mathrm{~cm}^{-2}$ and $27.77 \mathrm{~N} \mathrm{~cm}^{-2}$, respectively. With the variation of the sodium silicate content of the sand SA2 of $4.0 \%$ and $4.5 \%$, the values of tensile strengths reached, respectively, $32.53 \mathrm{~N} \mathrm{~cm}^{-2}$ and $40.77 \mathrm{~N} \mathrm{~cm}^{-2}$. The increase in the sodium silicate content from $3.5 \%$ to $4.0 \%$ represents an increase in the tensile strength value of the SA2 sand of $25.3 \%$. When the variation in content is from $3.5 \%$ to $4.5 \%$ the increase in strength is $57.0 \%$.

The bending strength with standard content of sand SAI, SA2, NI and ST reached the respective values of $65.50 \mathrm{~N} \mathrm{~cm}^{-2}, 67.83 \mathrm{~N} \mathrm{~cm}^{-2}, 55.17 \mathrm{~N} \mathrm{~cm}^{-2}$ and $89.33 \mathrm{~N} \mathrm{~cm}^{-2}$. By varying the silicate content in the SA2 sand in $4.0 \%$ and $4.5 \%$, the respective resistance values were $74.00 \mathrm{~N} \mathrm{~cm}^{-2}$

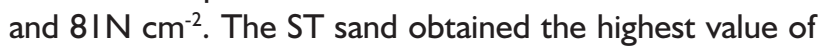

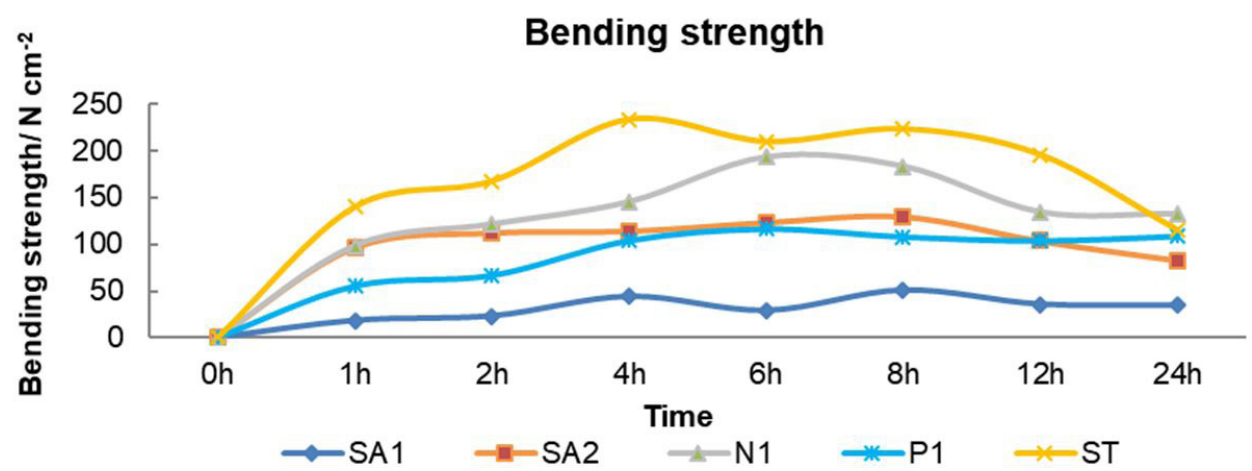

Figure 7. Bending strength as a function of time of cold set.

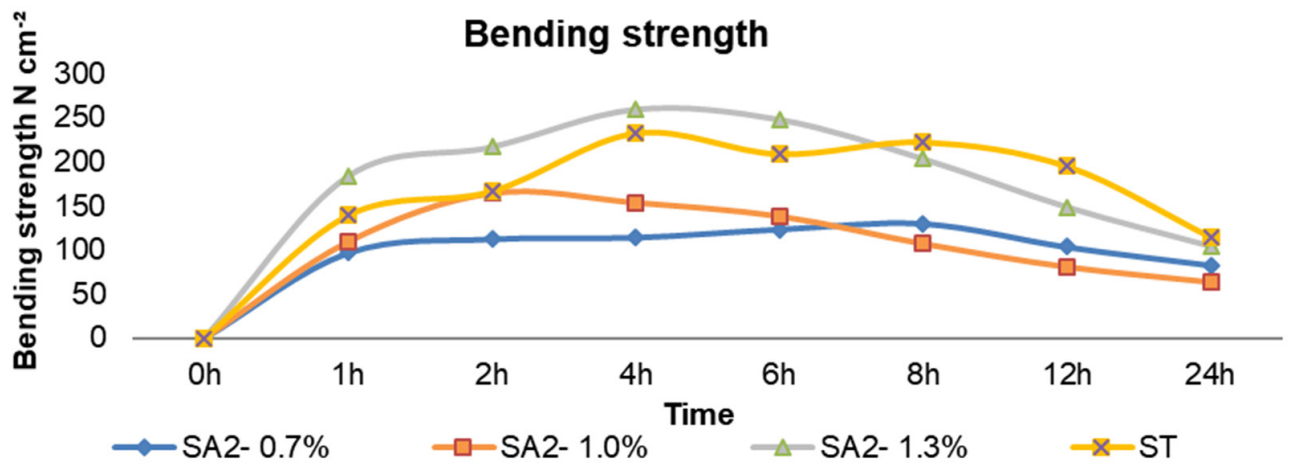

Figure 8. Bending strength as a function of time: variation of the resin content of sand SA2.

Table 6. Test results of sand samples with sodium silicate/ $/ \mathrm{CO}_{2}$

\begin{tabular}{|c|c|c|c|c|}
\hline Sample & SAI & SA2 & NI & ST \\
\hline Tensile strength/ $\mathbf{N}$ cm$^{-2}$ & 19.40 & 25.97 & 27.77 & 33.57 \\
\hline Bending strength/ $\mathbf{N} \mathrm{cm}^{-2}$ & 65.50 & 67.83 & 55.17 & 89.33 \\
\hline
\end{tabular}

Table 7. Results of the tests of the sand sample SA2 varying the levels of sodium silicate

\begin{tabular}{|c|c|c|c|}
\hline Sample & SA2-3.5\% & SA2-4.0\% & SA2-4.5\% \\
\hline Tensile strength/ $\mathbf{N ~ c m}{ }^{-2}$ & 25.97 & 32.53 & 40.77 \\
\hline Bending strength/ $\mathbf{N}$ cm$^{-2}$ & 67.83 & 74.00 & 81.00 \\
\hline
\end{tabular}


bending strength $\left(89.33 \mathrm{~N} \mathrm{~cm}^{-2}\right)$, even with the increase of the silicate content in sand SA2. With the variation of sodium silicate content for SA2 sand from $3.5 \%$ to $4.0 \%$ the bending strength increased by about $9.1 \%$ while for the $4.5 \%$ increase in sodium silicate the increase was $19.4 \%$.

\section{CONCLUSIONS}

The characterization of a material with employment potential in the industry is one of the most important steps for its acceptance. The variation of the binder contents in relation to the reference value in the processes of cold set and sodium silicate/ $\mathrm{CO}_{2}$ could be effective ways to make possible use of SA2 sand.in the foundry industry.

The SAI sand presented characteristics such as, wide particle size distribution, low permeability and high fines content, which shown that is not desirable for use as molding sand. The possibility to transform a waste material into an industrial product brings with it important concepts of sustainability. In addition, it is necessary to conduct bench scale tests with SA2 sand prior to application in the foundry industry.

According to internal data of Siderúrgica Itabirito-the referenced midsized company- it would be necessary about 60 tons of silica sand per month. Thus, the annual expenditure would be, approximately, 720 tons. In 2015, Samarco has produced 17.493 .593 tons of flotation tailings. Since 12\% of the total amount of flotation tailings can be used as foundry sand, available amount would be of around 2.100.000 tons.

\section{Acknowledgements}

The authors are grateful to Samarco, Siderúrgica Itabirito, CTF-Vale, SENAI- Itaúna, FEOP and Gorceix Foundation for their support in the execution of this study.

\section{REFERENCES}

I Mendes M, Lobato LM, Kunzmann M, Halverson GP, Rosière CA. Iron isotope and REE +Y composition of the Cauê banded iron formation and related iron ores of the Quadrilátero Ferrífero, Brazil. Mineralium Deposita. 2016;52(2):159-180.

2 Melo VAR, Lameiras FS, Tolentino E. Conversion of sandy tailing from banded iron formation exploitation into glassceramic materials. Materials Research. 2012;15(I):15-20.

3 Nociti DM, Campos E, Pereira MS, Bittencourt RM, Melo FCL. Study of ceramic block manufacure with the addition of waste from iron ore extraction. Materials Science Forum. 2014;798-779:275-280.

4 Freire CB, Cuccia V, Santos TO, Tello CCO, Lameiras FS. Radioactivity assessment of pavement blocks made with Itabirite ore waste. Revista Brasileira de Pesquisa e Desenvolvimento. 20I3;14:55-6I.

5 Muchon LGO. Caracterização de areias silicosis de Minas Gerais, Brazil, usadas em moldagem [Tese de doutorado]. Belo Horizonte: Universidade Federal de Minas; 1988.

6 Stauder BJ, Kerber H, Schumacher P. Foundry sand core property assessment by 3-point bending test evaluation. Journal of Materials Processing Technology. 2016;237:188-196.

7 Luz AB, Lins FF. Areia industrial. In: Luz AB, Lins FF, editores. Rochas e minerais industriais: uso e especificações. Rio de Janeiro: Ministério de Ciência e Tecnologia; 2005. I07-I26.

8 Conselho Executivo das Normas-Padrão [página da internet]. 2015. General index of the recommendations manual [cited 2017 feb 20]. Available at: http://www.tecnofund.com.br/cemp/indice.htm

9 Basa DK, Kumar T, Seshadri V. Influence of binder content, gassing time and gassing techniques on $\mathrm{CO}_{2} / S_{\text {ilicate }}$ process. Indian Foundry Journal. 1976;22:I-7.

10 Peixoto F. Regeneração térmica de areia ligada quimicamente [Tese de doutorado]. Joinville: Universidade do Estado de Santa Catarina; 2003.

II Winkler E, Bol'shakov A. Characterization of foundry sand waste. chelsea center for recycling and economic development. Massachusetts: University of Massachusetts; 2000.

$12 \mathrm{Ji} \mathrm{S}$, Fan Z. Improving the roundness of foundry sands with artificial processing. International Journal of Cast Metals Research. 2001;14:1-18.

I3 Ademoh NA. Effect of kaolin clay addition on mechanical properties of foundry sand moulds bonded with grades I and 2 Nigerian acacia species. International Journal of Physical Sciences. 2008;3:240-244. 
Figueiredo et al.

I4 Ziegler MJ. Foundry sand basics: a quick reference guide to the most fundamental and most used- foundry consumable product. Cleveland: Foundry Management and Technology; 1994. p. 25-29.

15 Carey PR, Lott M. Sand binder systems. Part V- Furan no-bake. Foundry Management and Technology. 1995; I:26-30.

Received: II Jun. 2018

Accepted: 23 Nov. 2018 